Article

IQBAL, M.A. ${ }^{1 *}$

ABDUL, H. ${ }^{1}$

MUZAMMIL, H.S. ${ }^{1}$

IMTIAZ, H. ${ }^{1}$

TANVEER, A. ${ }^{2}$

SAIRA, I. ${ }^{1}$

ANSER, A. ${ }^{2}$

\title{
A MetA-ANALYSis OF THE IMPACT OF FOLIAR FEEDING OF MicRonutrients ON PRODUCTIVITy AND REVENUE Generation OF Forage Crops
}

\section{Uma Meta-Análise sobre o Impacto da Adubação Foliar com Micronutrientes na Produtividade e Geração de Receitas de Culturas Forrageiras}

\begin{abstract}
Food security assurance to meet the demands of increased population growth requires a proportional increase in milk and meat production which, in turn, depends on animal nutrition. Assessing foliar application of micronutrients for production of substantive quantities of good quality forage must be a goal of modern, profit-oriented, sustainable agriculture and plants with better competitive ability as compared to weeds. This meta-analysis made a quantitative and qualitative analysis of the impact of foliar feeding of micronutrients (iron, zinc, copper, sulfur and boron) on forage crops under varying pedo-climatic conditions. Weighted and unweighted meta-analyses were performed on 139 studies to evaluate 19 independent variables (9 qualitative, 5 qualitative, 5 economic) in comparison to no spray of micronutrients. Foliar feeding through application of one, two or more micronutrients with single or multiple sprays positively influenced agronomic and physiological traits, which led to significantly higher green forage (7-19\%) and dry matter biomass. Nutritional quality, particularly crude protein (1.9-11.0\%) and digestibility (8-17\%), was improved by foliar spraying of micronutrients. Economic outputs were also increased as additional benefits rendered by foliar applied micronutrients surpassed their expenditures. For this data set, it is concluded that foliar feeding of micronutrients has the potential to boost forage yield, nutritional quality and revenue of cereals, legumes and non-conventional forage crops (quinoa and medick) depending on soil fertility status, concentration of applied micronutrients, number of foliar sprays, crop growth stage for foliar feeding and specific agro-environmental conditions.
\end{abstract}

Keywords: economic returns, plant nutrition, sprays, weighted meta-analysis, zinc.

* Corresponding author:

<aamir1801@yahoo.com>

Received: December 17, 2017

Approved: February 27, 2018

Planta Daninha 2019; v37:e019189237

Copyright: This is an open-access article distributed under the terms of the Creative Commons Attribution License, which permits unrestricted use, distribution, and reproduction in any medium, provided that the original author and source are credited.

\begin{abstract}
RESUMO - A garantia de segurança alimentar frente ao aumento da população exige incremento proporcional da produção de leite e carne, que por sua vez depende da nutrição animal. Avaliar a adubação foliar com micronutrientes para produção de quantidades substanciais de forragem de boa qualidade deve ser um objetivo da agricultura moderna, com fins lucrativos e sustentável, além da produção de plantas com melhor capacidade competitiva em relação às plantas daninhas. Essa meta-análise avaliou quantitativa e qualitativamente o impacto da adubação foliar com micronutrientes (ferro, zinco, cobre, enxofre e boro) em culturas forrageiras sob diferentes condições pedoclimáticas. Meta-análises ponderadas e não ponderadas foram realizadas em 139 estudos para avaliar 19 variáveis independentes (9 qualitativas, 5 qualitativas e 5 econômicas) em comparação com a ausência de pulverização de micronutrientes. A adubação foliar com aplicação exclusiva ou de dois ou mais micronutrientes através de pulverizações simples ou múltiplas influenciou positivamente as características
\end{abstract}

${ }^{1}$ University of The Poonch Rawalakot (AJK), Pakistan; ${ }^{2}$ Ghazi University, D.G. Khan, Pakistan. 
agronômicas e fisiológicas, que resultaram em uma forragem significativamente mais verde (7-19\%) e maior biomassa de matéria seca. A melhoria da qualidade nutricional, em particular da proteína bruta (1,9-11,0\%) e da digestibilidade (8-17\%), foi obtida pela pulverização foliar de micronutrientes. As mudanças econômicas também foram maiores, pois os benefícios adicionais resultantes da adubação foliar de micronutrientes foram maiores que os custos envolvidos. Para esse conjunto de dados, concluise que a adubação foliar de micronutrientes tem potencial de aumentar o rendimento forrageiro, a qualidade nutricional e a receita advinda da produção de cereais, leguminosas e culturas forrageiras não convencionais (quinoa e alfafa), dependendo do estado da fertilidade do solo, da concentração dos micronutrientes aplicados, do número de pulverizações foliares, do estágio de crescimento das culturas para fins de adubação foliar e das condições agroambientais específicas.

Palavras-chave: retornos econômicos, nutrição vegetal, pulverizações, meta-análise ponderada, zinco.

\section{INTRODUCTION}

Forages are an indispensable component of ruminant production systems across the globe. Forages provide protein, fiber, energy, vitamins and other minerals to ensure sustainable production and good health of dairy animals (Iqbal et al., 2017a, b). Animal productivity is directly influenced by agro-qualitative attributes of forages which, in turn, are affected by micronutrients (Kumar et al., 2016). Crops need 17 nutrients to complete their life cycle under ideal conditions (Samadhiya, 2017) while emphasis has been placed on macronutrients only. Micronutrients (zinc, copper, iron, manganese, boron, molybdenum, chlorine and nickel) are equally important for crop growth and development (Ahmed and Qadir, 2017). To date, there is no concrete evidence that silicon, sodium, vanadium and cobalt are essential for forage crops (Afzal et al., 2015).

Soil application is the most common and effective method to supply essential nutrients to forage crops (Iqbal et al., 2017a). However, micronutrients can also be supplied through foliar application to correct nutrient deficiency in the quickest way possible (Singh et al., 2011). Nutrients can be foliar applied in single or multiple sprays, but the risk of rain washing off the sprayed nutrients is high (Khalid et al., 2013). Furthermore, crop plants having wider leaf area were more responsive to foliar applied micronutrients but leaf damage owing to higher concentration of micronutrients have also been reported (Moosavi and Ronaghi, 2010; Kumar et al., 2014). Foliar application of iron chelates and ferrous sulphate was found to be more effective in correcting iron deficiency under calcareous soil as compared to fertigation (El-Fouly et al., 2011; Tewari, 2013; Iqbal et al., 2015a, b). Supplemental application of micronutrients as foliar sprays in addition to soil applied macronutrients was instrumental in boosting economic yield as well as economic returns (Ahmed and Qadir, 2017).

The impact of foliar applied micronutrients on forage crops needs to be assessed at varied levels to make sound decisions, evidence-based recommendations and their proper dissemination through targeted strategies. Micronutrient efficacy (degree and extent to which foliar applied micronutrients render a beneficial impact under ideally formulated conditions) and effectiveness (extent and degree to which foliar applied micronutrients serve the purpose of their application under field conditions) must be demonstrated and compared under varied agroclimatic conditions. Efficacy and effectiveness investigations about micronutrient foliar application should be judged on a biological horizon for boosting forage productivity, quality and profitability.

Meta-analysis has the potential to focus on overall existing research coherently by analyzing and comparing individual studies and also by providing reliable and robust research findings (Lehmann et al., 2014), conclusions and recommendations by following a well-documented and systematic methodology (Baranski et al., 2014). Although there have been some qualitative syntheses addressing the impact of foliar applied micronutrients on crop productivity, to the best of our knowledge, no meta-analysis has been conducted to quantitatively synthesize, analyze and evaluate the impact of micronutrients on productivity and profitability of forage crops under varied agroecological and agroenvironmental conditions. Therefore, this meta-analysis postulated the following hypotheses: (i) Foliar applied micronutrients may improve total biomass production 
of forage crops under various agro-environmental conditions; (ii) Nutritional quality of forage crops is improved with foliar application of one or more micronutrients in various concentrations. (iii) Foliar application of micronutrients as one or more sprays enhances economic outputs of farmers across the range of forage crops.

\section{MATERIALS AND METHODS}

The statistical approach of meta-analysis which integrated and compared the findings of various independent investigations addressing similar research questions (effectiveness of micronutrients) and problems (efficacy of foliar applied micronutrients) was used for an effective comparison in a way which is interpretable. For each selected field or laboratory investigation, a separate statistic referred to an effect size framed for quantification of the impact of micronutrient foliar application across studies (Baranski et al., 2014). Finally, a summary effect size was calculated to have an overall quantification of impact experimental treatments with respect to productivity and profitability of forage crops.

A search on the literature relative to the study was performed on Google Scholar (http:// scholar.google.com) and PubMed (http://www.PubMed.gov) by using the following search strings: (1) micronutrients and forages, (2) micronutrients and profitability and (3) forage productivitymicronutrients. The search was restricted to the time period of 2000-2017 and a total of 349 research studies were retrieved. The data and research studies were screened and filtered, and research studies only were included in the meta-analysis if they reported (a) the impact of at least one micronutrient on forage biomass production; (b) the effect of one or more micronutrients on agro-qualitative attributes of forage crops; (c) profitability of forage crops as influenced by foliar applied micronutrients applied solely or in combination with other treatments and interferences; (d) dose optimization of different micronutrients for boosting productivity and profitability of cereal and leguminous forage crops; (e) impact of micronutrient foliar application on economic outputs of forages in comparison to no application, and (f) studies reporting a measure of variance either as standard variance or standard error, ANOVA tables, t test, Tuckey HSD, orthogonal contrasts, least significant difference or any other statistical analysis.

After the screening process, 139 studies were found to be fully fit in the objectives and selection criteria of our meta-analysis. Only 11 non-peer reviewed research studies were retrieved but they were rejected later to minimize potential bias as peer-review was used as the criteria of quality research. Furthermore, farm surveys, case studies and controlled studies were also excluded with a view to enhancing the reliability and validity of our meta-analysis.

The collected research studies were divided into 3 distinct groups: (1) impact of micronutrients on forage biomass (plant height, stem diameter, number of leaves, leaf area, fresh and dry plant weights, green forage yield and dry matter biomass) (101 studies); (2) effect of micronutrients on forage quality (digestibility, protein, fiber, fats and total ash) (32 investigations), and (3) profitability of forage crops as influenced by foliar applied micro-nutrients (19 research studies). The studies which reported two or more aspects were considered and analyzed in one research aspect only.

Weighted (standard random effects weighted by a common random effect variance and inverse variance) and unweighted (based on statistical differences in means) meta-analyses were carried out for experimental variables as influenced by foliar applied micronutrients with the R-Statistical software program. Effect sizes based on standardized mean differences were used in weighted meta-analysis, while the Metafor statistical package (Baranski et al., 2014) was used for determining the standardized mean differences as basic response variable. Homogeneity tests (Q and $P$ statistics) were employed on summary effect sizes. If $P$ values were less than $25 \%$ and $P$ values were greater than 0.01 , then homogeneity was declared (Lehmann et al., 2014). In order to conduct unweighted meta-analysis, the ratio of foliar applied micro-nutrients: no foliar spray means depicted in percentage were in-transformed. The resulting values were further used to determine the statistical significance of in-transformed values by employing re-sampling. Fisher's one sample randomization test was employed to derive $p$ values with a level of significance of $p<0.05$. 


\section{RESULTS AND DISCUSSION}

As per the meta-analysis, foliar application alone or combined of $\mathrm{Fe}, \mathrm{Zn}, \mathrm{Mn}$ and $\mathrm{Cu}$ was instrumental (Table 1) in increasing plant height of cereals $(21 \%)$, legumes $(24 \%)$ and nonconventional crops (quinoa and medics) (9\%) (Figure 1). The increment in stem girth, flag leaf width and length led to significantly higher forage yield of cereals $(19 \%)$, legumes $(12 \%)$ and nonconventional crops (7\%), while dry matter biomass of forage crops was also increased by $19-27 \%$. The impact of foliar applied micronutrients was non-significant $(P \leq 0.05)$ for stem diameter of legumes and non-conventional forage crops and width of flag leaf of non-conventional crops only. Cereal forages, particularly sorghum, maize and barley, responded vigorously to foliar applied micronutrients under varied agro-climatic conditions and soil classes, followed by leguminous crops (cowpea, cluster bean, soybean, rice bean, alfalfa etc.). The non-conventional crops (medics and quinoa) also responded positively. However, the increase in their biomass productivity was below par as compared to cereal and legume forages. Overall, biomass production of forages was positively affected by foliar application of different micronutrients, while concentration and number of foliar sprays of micronutrients, along with the growth stage of crop plants, determined the efficacy of applied nutrients. Similarly, cereals responded vigorously to foliar feeding of micronutrients in terms of crop growth rate and net assimilation rate, while leguminous forages recorded lesser biomass increment than cereals (Figure 1).

Foliar applied nano-iron (Fe) chelates and chemical iron chelates increased plant height and forage yield of maize by improving membrane integrity and phytochromic activity

Table 1 - Weighted and unweighted meta-analyses (M.A.) based on mean percentage difference (MPD) and standard mean differences (SMD) for agronomic and physiological yield attributes of forage (cereals, legumes and unconventional) crops

\begin{tabular}{|c|c|c|c|c|c|}
\hline \multirow{2}{*}{ Variable } & \multicolumn{3}{|c|}{ Unweighted meta-analysis } & \multicolumn{2}{|c|}{ Weighted meta-analysis } \\
\hline & $\mathrm{N}$ & Ln ratio & $p^{*}$ & $\mathrm{n}$ & $p^{*}$ \\
\hline Plant height $(\mathrm{P})$ & 17 & 7.45 & $<0.001$ & 13 & $<0.005$ \\
\hline Stem diameter $(\mathrm{SG})$ & 22 & 5.21 & 0.100 & 8 & 0.490 \\
\hline Number of leaves (NL) & 16 & 5.20 & 0.180 & 15 & 0.630 \\
\hline Flag leaf length (FL) & 9 & 7.91 & 0.005 & 6 & $<0.001$ \\
\hline Flag leaf width (FLW) & 13 & 5.04 & 0.290 & 9 & 0.798 \\
\hline Crop growth rate (CGR) & 5 & 7.98 & $<0.005$ & 19 & $<0.001$ \\
\hline Net assimilation rate (NAR) & 5 & 8.16 & $<0.001$ & 27 & 0.001 \\
\hline Green forage yield (GFY) & 19 & 11.78 & $<0.005$ & 33 & $<0.005$ \\
\hline Dry matter biomass (DMB) & 26 & 13.65 & $<0.001$ & 37 & $<0.005$ \\
\hline
\end{tabular}

$\mathrm{n}=$ number of study data points, $<\mathrm{p}^{*}=$ significant difference with respect to control treatment, Ln ratio $=$ foliage feeding $/$ control $\times 100$.

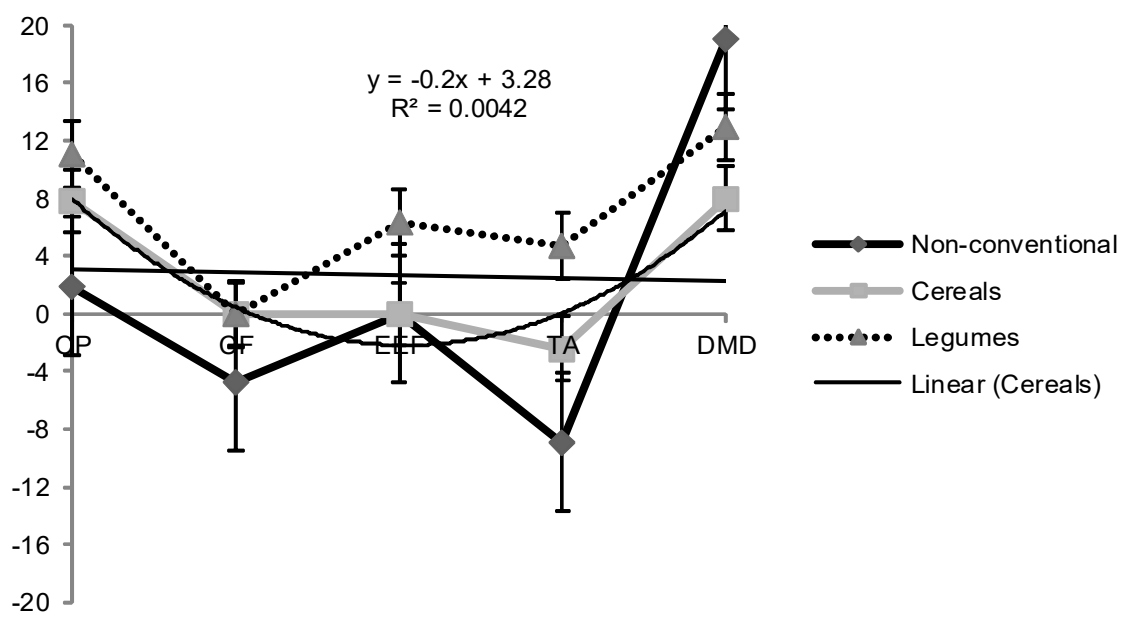

Figure 1 - Cumulative impact of foliar feeding of micronutrients on yield attributes, green forage yield and dry matter biomass of cereals, legumes and unorthodox biomass crops. 
(Kumar et al., 2016). Foliar feeding of copper (Cu) increased utilization efficacy of ammonium N and triggered the synthesis of auxins and protected cereals from frost and weedicide injury (Ahmed and Qadir, 2017). Foliar applied Fe chelates were instrumental in boosting physiological growth of forage crops by activating numerous enzymes required in photosynthesis and respiration and for chlorophyll synthesis. Foliar applied $\mathrm{Zn}$ triggered the metabolism of carbohydrates and protein which increased stem elongation (Nadim et al., 2012). Similarly, Fe foliar feeding increased herbage yield by improving partitioning of assimilates and the source-sink relationship (Ali et al., 2014).

The meta-analysis depicted a significant influence of micronutrients on revenue generation and nutritional quality of forage crops (Table 2). The foliar applied micronutrients caused an increase of $2-6 \%$ in the cost of production of forage crops; however, the increase in gross income and net income was 9.5-16.8\% and 7.1-12.3\%, respectively (Figure 2). Cereals generated the highest revenues in response to foliage feeding of micronutrients, followed by forage legumes, while unorthodox biomass crops gave the lowest economic returns. Cereals also remained unmatched in terms of benefit-cost ratio (BCR) (2.21), while legumes with BCR of 1.74 followed cereal crops, which in turn were followed by non-conventional crops.

Table 2 - Weighted and unweighted meta-analyses (M.A.) based on mean percentage difference (MPD) and standard mean differences (SMD) for revenue generation and nutritional quality of forage (cereals, legumes and unconventional) crops

\begin{tabular}{|c|c|c|c|c|c|}
\hline \multirow{2}{*}{ Variable } & \multicolumn{3}{|c|}{ Unweighted meta-analysis } & \multicolumn{2}{|c|}{ Weighted meta-analysis } \\
\hline & $\mathrm{n}$ & Ln ratio & $p^{*}$ & $\mathrm{n}$ & $p^{*}$ \\
\hline \multicolumn{6}{|c|}{ Economic analysis } \\
\hline Cost of production $(\mathrm{CP})$ & 6 & 5.29 & $<0.005$ & 4 & $<0.005$ \\
\hline Gross income (GI) & 9 & 4.18 & $<0.005$ & 7 & $<0.005$ \\
\hline Net income (NI) & 6 & 7.91 & $<0.001$ & 18 & $<0.001$ \\
\hline Benefit-cost ratio (BCR) & 13 & 3.29 & $<0.005$ & 11 & $<0.001$ \\
\hline Marginal rate of return (MRR) & 4 & 6.87 & $<0.001$ & 9 & $<0.005$ \\
\hline \multicolumn{6}{|c|}{ Forage quality } \\
\hline Crude protein $(\mathrm{CP})$ & 9 & 4.05 & 0.001 & 5 & $<0.005$ \\
\hline Crude fiber $(\mathrm{CF})$ & 11 & 7.27 & 0.458 & 17 & 0.584 \\
\hline Ether extractable fat (EEF) & 6 & 5.25 & 0.519 & 9 & 0.879 \\
\hline Total ash (TA) & 12 & 6.87 & $<0.005$ & 7 & $<0.005$ \\
\hline Digestibility (DMD) & 19 & 9.21 & $<0.005$ & 12 & $<0.005$ \\
\hline
\end{tabular}

$\mathrm{n}=$ number of study data points, $<\mathrm{p}^{*}=$ significant difference with respect to control treatment, Ln ratio $=$ foliage feeding/control $\times 100$.

Foliar applied $\mathrm{Cu}, \mathrm{Fe}$ and $\mathrm{Zn}$ resulted in higher economic returns, particularly on soils which were calcareous and alkaline with abundance of carbonates and bicarbonates, ionic imbalances and pollution (Ryan et al., 2013). Higher biomass production resulted in a significant increase in economic returns, and higher quality forage also fetched better market price for better feeding value (Iqbal et al., 2015a, b). Similarly, the benefit-cost ratio which represents additional profit earned for each additional unit of expenditures was found to be higher than 1 for all forage crops, which depicted foliar applied nutrients as an economically viable strategy. Marginal rate of returns were also improved with foliar feeding of micronutrients as the economic gains owing to higher productivity overpassed minute expenditures of micronutrients (Mirzapour et al., 2013). Thus, not only the biological feasibility of foliar spraying of micronutrients for forage crops was established but their economic viability was also proven (Kumar et al., 2014).

The impact of foliar applied micronutrients was significant $(P \leq 0.05)$ for agro-qualitative attributes of cereals and leguminous crops under both tropical and temperate climates (Figure 2). Crude protein and dry matter digestibility were improved by $1.9-11 \%$ and $8-19 \%$, respectively. Foliar applied micronutrients decreased crude fiber content of non-traditional crops, while its impact was non-significant for cereals and legume forage crops. An increasing trend for ether extractable fats of forage legumes was found in response to foliar applied micronutrients, while it remained non-significant for cereals and non-conventional crops. There was a downward trend 

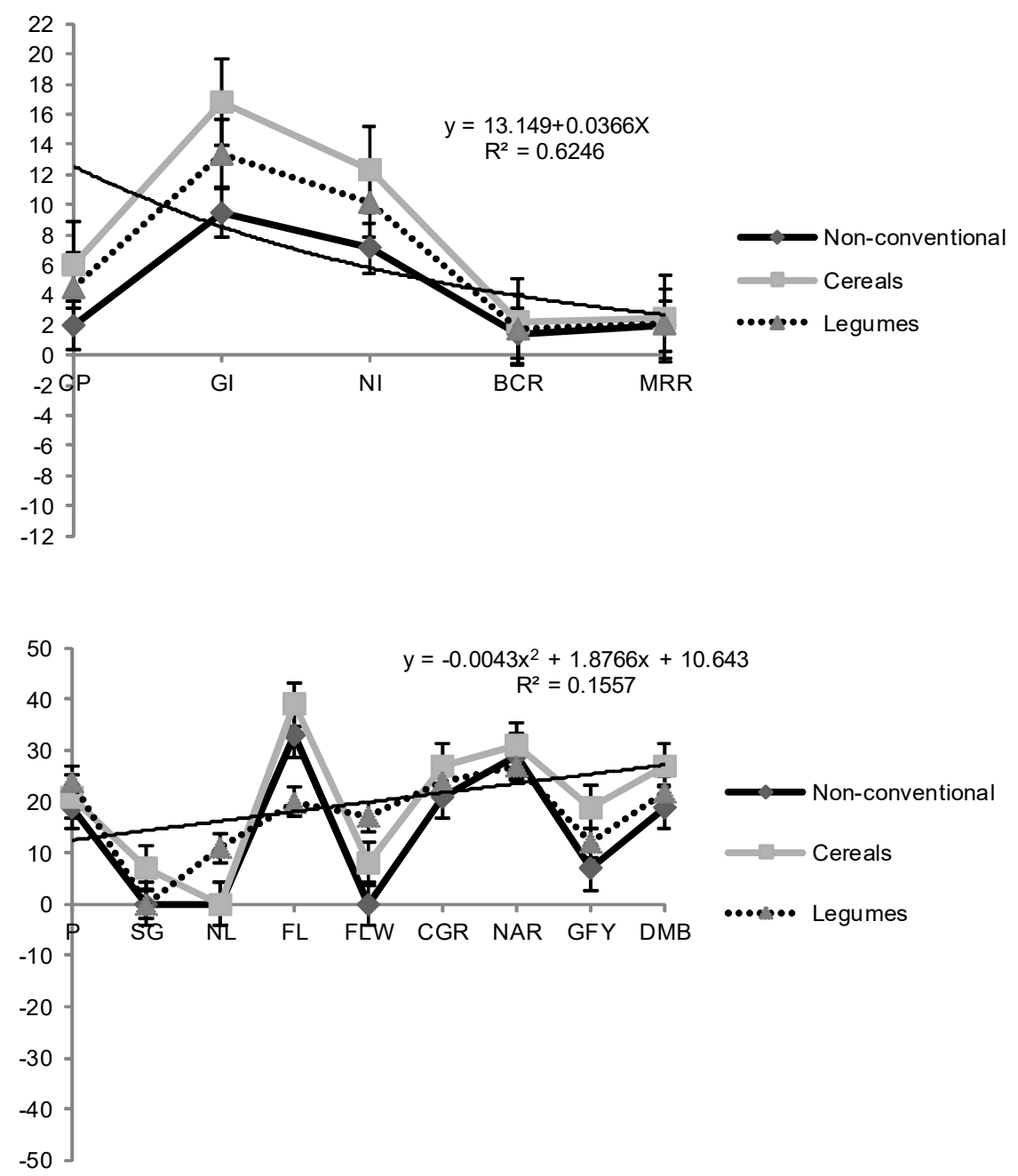

Figure 2 - Cumulative impact of foliar feeding of micronutrients on revenue generation and nutritional quality of cereals, legumes and unorthodox biomass crops.

for total ash in legumes and non-traditional forage crops; however, cereals responded positively to foliar application of micronutrients as far as total ash was concerned.

Micronutrients uptake reduced sharply in the wake of higher application of phosphorous fertilizers, particularly in calcareous soils with low organic matter. The quality of forage maize, especially protein and carbohydrates, was increased with foliar application of chemical and nanoiron $(\mathrm{Fe})$ chelates. Fe is an integral constituent of heme and non-heme protein, including ferrodoxin, and it is a part of the chloroplast, where it triggered sulphur and $\mathrm{N}$ metabolism, which caused an increase in protein content. Furthermore, Fe deficiency resulted in yellowing of leaves, which reduced protein content by 11-59\% (Singh et al., 2011). Similarly, Zn also serves as a precursor of tryptophan and its spray was effective in increasing protein content and reducing fiber content (Sajad et al., 2014). Owing to slower movement of $\mathrm{Zn}$ within plants, its foliar spray prevented yellowing of leaves and, ultimately, protein was significantly increased. $\mathrm{Fe}, \mathrm{Cu}$ and $\mathrm{Zn}$ chelates applied as a foliar spray in amalgamation with amino acids such as methionine and glycine increased protein content owing to improved N nutrition. Fe spray (100-200 ppm) activated and increased nitrate reductase, which increased protein and decreased fiber and, ultimately, digestibility of forage was enhanced (Rana et al., 2013).

Based on these findings, it may be inferred that foliage feeding of micronutrients has the potential to effectively improve the agronomic and physiological growth traits of forage crops, which resulted in higher biomass production. Cereals responded more pronouncedly to foliar applied micronutrients in terms of dry matter yield and revenue generation compared to legumes and non-conventional biomass crops. Foliar application of different micronutrients served 
effectively to boost the nutritional quality of forage by improving digestibility, protein, fat and ash content while decreasing fiber content. The efficacy of foliage feeding of micronutrients relied on concentration of micronutrients, number of sprays and growth stage of crop along with pedo-climatic conditions.

\section{REFERENCES}

Afzal MI, Iqbal MA, Cheema ZA. Triggering growth and boosting economic yield of late-sown wheat (Triticum aestivum L.) with foliar application of allelopathic water extracts. World J Agric Sci. 2015;11(2):94-100.

Ahmed M, Qadir MA. Sorghum stalk yield and grain nutritional quality improvement by foliar metal chelates. Pak J Bot. 2017;49:109-14.

Ali B, Ali A, Tahir M, Ali S. Growth, seed yield and quality as influenced by foliar application of iron sulfate. Pak J Life Soc Sci. 2014;12(1):20-5.

Baranski M, Erednicka-Tober D, Volakakis N, Seal C, Sanderson R, Stewart GB, et al. Higher antioxidant and lower cadmium concentrations and lower incidence of pesticide residues in organically grown crops: a systematic literature review and metaanalyses. Brit J Nutr. 2014;112(5):794-811.

El-Fouly MM, Mobarak ZM, Salama ZA. Micronutrients (Fe, Mn, Zn) foliar spray for increasing salinity tolerance in wheat (Triticum aestivum L.). Afr J Plant Sci. 2011;5(5):314-22.

Iqbal MA, Bethune BJ, Iqbal A, Abbas RN, Aslam Z, Khan HZ, et al. Agro-botanical response of forage sorghum-soybean intercropping systems under atypical spatio-temporal patterns. Pak J Bot. 2017b;49(3):987-94.

Iqbal MA, Iqbal A, Ahmad Z, Raza A, Nabeel F. Overviewing forage maize yield and quality attributes enhancement with plant nutrition management. World J Agric Sci. 2015b;11(3):128-134.

Iqbal MA, Iqbal A, Aslam Z, Maqsood M, Ahmad Z, Akbar N, et al. Boosting forage yield and quality of maize (Zea mays L.) with multi-species bacterial inoculation in Pakistan. Phyton. 2017a;86:84-8.

Iqbal MA, Qaiser M, Ahmad Z, Saleem AM, Afzal S, Ahmad B. A preliminary study on plant nutrients production as combined fertilizers, consumption patterns and future prospects for Pakistan. Am Eur J Agric Environ Sci. 2015a;15(4):588-94.

Khalid F, Tahir M, Fiaz N, Nadeem MA, Khalid F, Gillan S. Hybrid maize response to assorted chelated and non-chelated foliar applied zinc rates. J Agric Technol. 2013;9(2):295-309.

Kumar B, Dhaliwal SS, Singh T, Lamba JS, Ram H. Herbage production, nutritional composition and quality of teosinte under Fe fertilization. Int J Agric Biol. 2016;18(2):319-29.

Kumar B, Lamba JS, Dhaliwal SS, Sarlach RS, Ram H. Exogenous application of bio-regulators improves grain yield and nutritional quality of forage cowpea (Vigna unguiculata). Int J Agric Biol. 2014;16(4):759-65.

Lehmann A, Veresoglou SD, Leifheit EF, Rillig MC. Arbuscular mycorrhizal influence on zinc nutrition in crop plants - A metaanalysis. Soil Biol Biochem. 2014;69:123-31.

Mirzapour MH, Khoshgoftarmanesh AH. Effect of soil and foliar application of iron and zinc on quantitative and qualitative yield of pomegranate. J Plant Nutr. 2013;36:55-66.

Moosavi AA, Ronaghi A. Growth and iron-manganese relationships in dry bean as affected by foliar and soil applications of iron and manganese in calcareous soil. J Plant Nutr. 2010;33:1353-65.

Nadim MA, Awan IU, Baloch MS, Khan EA, Naveed K, Khan MA. Response of wheat (Triticum aestivum L.) to different micronutrients and their application methods. J Anim Plant Sci. 2012;22:113-9.

Rana DS, Singh B, Gupta K, Dhaka Ak, Arya S. Response of fodder sorghum [Sorghum bicolor (L.) Moench] to zinc and iron. Forage Res. 2013;39:45-7.

Ryan J, Rashid A, Torrent J, Yau S, Ibrikci H, Sommer R, et al. Micronutrient constraints to crop production in the Middle EastWest Asia region: significance, research and management. Adv Agron. 2013;122:3-84. 
Sajad A, Jamil M, Ahmad M, Abbasi GH, Fakhar-u-Zaman M. An investigation on nitrogen-zinc interaction synergise maize (Zea mays L.) fodder quality. World Appl Sci J. 2014;31:91-5.

Samadhiya VK. Response of micronutrients and urea foliar spray on yield and nutrient uptake of safflower (Carthamus tinctorius L.) in Chhattisgarh plan. Int J Chem Stud. 2017;5:325-35.

Singh G, Nathawat NS, Kishore N, Ramani S, Ramaswamy NK, D’souza SF. Differential translocation of iron in iron sufficient and deficient sorghum plants. J Plant Nutr. 2011;34(11):1723-35.

Tewari BB. Determination of stability constants of metal (II)-methionine and metal (II)-methionine-cystiene (binary and mixed) complexes using the paper ionophoretic technique. J Plant Growth Regul. 2013;32:315-23. 